\title{
Individual spiritual capital: meaning, a conceptual framework and implications
}

\author{
Anselmo Ferreira Vasconcelos \\ Independent Researcher, São Paulo, Brazil
}

Individual spiritual capital

\begin{abstract}
Purpose - The purpose of this conceptual paper is to trigger a transcendental concern toward building the spiritual capital (SC) particularly focused on the highly relevant domain of work. In doing so, this conceptual framework focuses on potential antecedents and outcomes of the SC.

Design/methodology/approach - Such an endeavor is premised on the Christian's teaching that advocates the need for gathering spiritual treasures (i.e. capital). Secondly, the foray into Spiritism Doctrine (SD) literature is due to the fact that this doctrine considers the spiritual construct as the cornerstone of its principles and tenets. Thirdly, it also examines the related perceptions and approaches from the fields of positive psychology, positive organizational scholarship, workplace spirituality and psychology of religion.

Findings - The model invites the individual to capitalize on salient virtues and remarkable human qualities so as to build a SC, namely: humility, compassion, forgiveness, empathy, positive emotions, connections/ relationships and sense of cooperation. Finally, it is envisaged that the attempt to create a SC may lead the individual to a feeling of well-being and more resilience at work.

Practical implications - At last, the implications to develop a SC in the context of work are sizeable. After all, it implies to add more concerns to one's career much beyond those strictly functional or professional ones. Rather, it means to regard the work domain through unusual lens.

Originality/value - By bringing the conceptual framework of SC to the forefront of management, spirituality and religion studies through an interdisciplinary approach showed that it is not an elusive or mythical topic. On the contrary, this analysis revealed that this is a serious and surprisingly neglected issue that deserves further attention in light of the benefits that it can potentially yield.
\end{abstract}

Keywords Compassion, God, Spiritism doctrine, Spiritual, Values, Virtues

Paper type Conceptual paper

\section{Introduction}

The management parlance has largely incorporated the word "capital" into its domain, particularly in the last decades. Scholars have been extremely creative in elaborating distinct forms of gathering capital such as human capital, intellectual capital, social capital, psychological capital, wisdom capital, spiritual capital and so on. In this regard, human capital is associated with a range of skills, knowledge and capabilities that workers employ in order to accomplish their tasks and organizational goals (Pennings et al., 1998). Such a capital is fundamentally made up of scientists, executives, technicians, and their expertise is paramount for implementing innovation and creativity to help organizational outcomes. Similarly, the intellectual capital involves the sum of all the intangible resources of knowledge that an organization can use toward sustaining a competitive advantage and high financial

(C) Anselmo Ferreira Vasconcelos. Published in Journal of Work-Applied Management. Published by Emerald Publishing Limited. This article is published under the Creative Commons Attribution (CC BY 4.0) licence. Anyone may reproduce, distribute, translate and create derivative works of this article (for both commercial and non-commercial purposes), subject to full attribution to the original publication and authors. The full terms of this licence may be seen at http://creativecommons.org/licences/by/4.0/ legalcode

The author declares that he has no conflict of interest.

The author is very grateful to Prof Tony Wall and his editorial team as well as two anonymous reviewers for their comments and suggestions on an earlier version of this article. 
JWAM

13,1

118

performance (Youndt and Snell, 2004). Some authors proposed that this perspective embraces simultaneously social, organizational and human capital by enabling the organization a full understanding of critical resources (Su, 2014). Undeniably, knowledge constitutes the most important asset in the modern world and, as such, it stands out everyone who have it. In a related vein, it must be recognized the relevance of social capital, which encompasses the need for developing human relationships as so to engender new ideas, concepts and projects.

Social capital has been investigated for researchers devoted to political science, development studies, sociology, urbanism, organizational studies and management (Ayios et al., 2014). This sort of capital is pivotal in terms of the formulation of solutions to sensitive societal issues, given that it enables practical actions. Furthermore, people should hunker down toward gathering their own social capital. Building a useful network sounds a vital step in order to keep ascending their careers. In parallel, researchers have been working hard in the development of the psychological capital. This form of capital is considered as a high order construct, given that it embraces other constructs, that is, self-efficacy/confidence, optimism, hope and resistance (Luthans et al., 2007). Of note is that psychological capital has been intensely tested in distinct work environments and countries. Overall, each one of these approaches has been exhaustively theorized and, as a consequence, their theoretical frontiers are clearly outlined. In essence, the notion of capital underlines the need for gathering some sort of value.

More recently, scholars have proposed other form of capital, that is, wisdom capital. This is apparently related to individuals that are capable to act wisely, think wisely, judge wisely and behave wisely in the workplaces (e.g. Vasconcelos, 2018). Nevertheless, this is a new approach of capital that deserves more theoretical development. In a related vein, it must be pointed out that "Spiritual knowledge, competences, and preferences may be understood as valuable assets in the economy of symbolic goods" (Verter, 2003, p. 152). Going further, Zohar and Marshall (2004) proposed that spiritual capital (SC) should be seen as a new paradigm. According to their view, it implies in a radical change in our mindset, particularly in "the philosophical foundations and the practices of business" (p. 21). Moreover, SC does not focus on gaining monetary wealth, yet it does not put aside such a possibility through approaching business under the perspective of building "meaning and value" (p. 21). Zohar and Marshall (2004) suggested that SC "can generate profit that both draws on and adds to the wealth of the human spirit and to general human well-being" (p. 21). Accordingly, SC is a topic worthy of further theoretical development considering its singularity.

On the other hand, scholars advocate that we are already living in the era of the spiritual revolution (e.g. Tacey, 2004), although, there is no enough evidence to support such claim. Rather, the increasing array of problems related to environment, climate, violence, disruptions, as well as the widespread racial and ethnical resentment, social inequality and unhappiness do not sustain such an optimistic view. Confirming such a perception is the growing level of employees' disengagement noticed everywhere (Crabtree, 2013). In fact, it is clear that the exclusive materialistic concerns (i.e. the search for wealth and profit) have not provided a life satisfaction for all people in this planet. For these reasons, perhaps it is more accurate to state that the issue of spirit is slowly gaining ground in the humankind's minds and hearts. In other words, it appears that people are increasingly awakening to the transcendental dimension of life, i.e. the spiritual domain. In effect, this is not exactly a novel topic regarding the seminal work of Allan Kardec (1857/2003a, 1866/2003b, 1878/2005), which was carried out more than 160 years ago whereby he probed the spiritual life and its implications for us (incarnated spirits). As a result, his investigation laid down the foundation of spiritist or Spiritism Doctrine (SD) [1], [2].

In a broader sense, therefore, it appears that the spiritual capability may be vital to people to enable the inner-focused skills in order to cope with a range of harsh events, situations and problems (Vasconcelos, 2017a, p. 601). Taken as a whole, the purpose of this conceptual paper is to trigger a transcendental concern toward building the SC, particularly focused on the highly relevant domain of work. Such an endeavor is premised on the Christian's 
teaching that advocates the need for gathering spiritual treasures (i.e. capital) [3]. In doing so, this conceptual framework focuses on potential antecedents and outcomes of the SC. Secondly, the foray into SD literature is due to the fact that this doctrine considers the spiritual construct as the cornerstone of its principles and tenets. Accordingly, the revelations and findings derived from its body of knowledge are intriguing, insightful and enlightened, given that they offer a robust counterpoint to the materialistic paradigm that we live in. Thirdly, it also examines the related perceptions and approaches from the fields of positive psychology, positive organizational scholarship, workplace spirituality and psychology of religion.

\section{Theoretical background}

At the onset, it is worth remembering that SD - one of the pillars of this paper - is strongly grounded on the faith in the hereafter, the phenomenon of the spirits' messages and guiding principles through mediums, the Jesus Christ's teachings (the Gospel) and his behavior as a paradigm of perfection that should be followed by all human beings, and the practice of charity. Simply put, SD is the outcome of a blend of science, philosophy and religion. More specifically, "As a scientific endeavor, it studies the relationships between the physical and the spiritual worlds. As a philosophy, it deals with the moral implications of such relationships" (Kardec, 1865/2004, p. 12, italics in the original). In terms of religion, it "establishes the bonds of brotherhood and the communion of thoughts, not on a simple convention, but on a more solid basis: the very laws of Nature" (Kardec, 1868, p. 491, our translation). Most importantly, Kardec's (1868/2003c) findings revealed that "the spiritual element has an active part in the economy of the universe" (p. 20, italics added). Nowadays, it assumed that, "spirituality in one form or another touches every aspect of contemporary life" (Wolman, 2001, p. 11; see also King, 2008, p. 181; Culliford, 2014, p. 42).

\section{The constructs of religion and spirituality and their intersection}

Thus, before we advance in our journey, it is relevant to clarify even more what the constructs of religion and spirituality embrace. In this way, it is worth pointing out that the majority of people that live in the planet earth believe in some sort of religion and draws on such a means in order to develop their own spirituality. In fact, there is some evidence showing that religion is deeply ingrained in the history and future of humanity (Humphries et al., 2016). As put by Bouckaert (2011), "religions place great emphasis on institutional forms of contact with the sacred and the transcendent, mediated through rituals, sacred books, canonized traditions, dogmatic truths, and hierarchical relationships" (p. 26). Furthermore, religiousness tends to be formal, very organized and focused on dogmatic. To a large extent, their members are subjected to institutional, intolerant, negative and community-focused deliberations. Religion also is more observable, measurable, objective, authoritarian, as well as advocates a kind of behavior shaped by outward practices and more oriented toward doctrine features (Liu and Robertson, 2011).

Additionally, Vitell et al. (2016) suggest that "Religion tends to indicate a belief in a particular faith system, whereas spirituality involves the values, ideals, and virtues to which one is committed" (p. 148). To Fotaki et al. (2020, p. 10) spirituality encompasses the beliefs related to one's subjective perception concerning his/her relationships. In this regard, it may embrace a general view about the sacred or transcendent dimension of existence, i.e. one's convictions concerning self, others, the community, the world and values regarding moral conduct derived from such convictions. In essence, both alternatives (religion and spirituality) address the sacred (Exline and Bright, 2011). Given its nature and features, it seems that the spirituality construct is more equipped to help the individuals to build a SC. 
JWAM

13,1
The meaning of spirituality construct

Going further, it is important to outline how SC researchers have outlined it in order to better delimitate its scope, understanding and implications. In this sense, it is paramount to firstly untangle the meaning of spirituality, which is considered as a multidimensional and multifaceted construct. In a nutshell, spirituality is a broad and rich construct not subject to simple definitions or measurements. Given its transcendental nature, it enables a personal transformation (Emmons, 1999) as well as the development of the self (Ashforth and Pratt, 2003) by the assimilation of virtues and higher values toward the ultimate reality. It appears that by developing our spirituality we improve our sensibility "opening it to the most subtle and deepest aspects of that" (Lozano and Ribera, 2004, p. 178). Spirituality is also seen as an innate and universal mechanism of searching for transcendent meaning in the everyday happenings of life (Ashar and Lane-Maher, 2004; Pargament and Mahoney, 2005; Blanton, 2007). Taken together, spirituality has been construed as the search for meaning and purpose; the interconnectedness of all of creation; wholeness; inner potential; eventually rooted, as noted earlier, in religion and in the sacred for some; private and personal; employed for organizational and instrumental purposes; social concerns; the search for justice, peace nonviolence, ecological harmony; concerns with civil society, economics, business, management, good governance and work; actions that challenge inequalities; universal and sacred goals (Tacey, 2004; Zinnbauer and Pargament, 2005; Blanton, 2007; King, 2008; Srirangarajan and Bhaskar, 2011; Vasconcelos, 2010, 2015; Groen, 2018).

Following this line of reasoning, a study by Steffler and Murdoch (2017) concerning the concepts of meaning and spirituality found five themes, namely: ultimate concerns, integrity, service and care for others, health and well-being, generativity (meaning), death and afterlife (spirituality). Whereas other recent qualitative studies found evidence that data fitted into previous models of subdimensions of spirituality: (1) public practice, private practice, intellect, experience, ethics and ideology; (2) vertical connectedness (i.e. to higher spiritual being/God and to immaterial sphere), horizontal connectedness (to other humans, to all living entities, to decedents, to nature, to a greater whole and to universe) and depth dimension of connectedness (to self and to the body; Demmrich and Huber, 2019).

In addition, King (2008) suggested that:

Developing the social aspects of spirituality within a secular context need not be a sell-out of what spirituality is about. On the contrary, rightly understood, the nurturing of spiritual insights, motivation, and orientation can contribute to the transformation of people, the workplace, and global society. While spirituality begins at home, with the individual person and a small network of relationships, it must ultimately extend to the entire world. (pp. 182-183)

Building on the transformative idea of spirituality in the workplace means being engaged in self-actualization, making a difference and useful contributions, having a higher purpose, serving others, achieving connections with a higher universal power, enjoying the sensation and development of love, cultivating harmonic relationships and working toward delivering the higher good (Kinjerski and Skrypnek, 2004; Vazin, 2013). In more practical terms, it seems that the development of our spirituality (i.e. spiritual capital) in this corporeal dimension is closely intertwined with the experience of serving our neighbors, as well as actively cooperating to the common good and to the betterment of society as a whole. As rightly noted by Lips-Wiersma and Nilakant (2008), "A spiritual perspective would argue that our spiritual duty is to use our free will to help and not harm others to further their ends" (p. 59, italics added). Overall, it appears that spirituality is "a basic human good essential for human flourishing" (Williams, 2003, p. 1). Notwithstanding, we continue to live in a spiritually impoverished world owing to our selfish behavior and ignorance of universal laws. According to SD, there are 12 universal laws that cover very important aspects, namely: the divine or natural law, the 
law of adoration, the law of labor, the law of reproduction, the law of preservation, the law of destruction, the social law, the law of progress, the law of equality, the law of liberty, the law of justice, love, and charity and the law of moral perfection (Kardec, 1857/2003a).

Kardec (1857/2003a) found that some of the divine laws focus on physical nature and are usually domain of science, while others are concerned with the individuals and their relationships with God and their fellows. The latter are labeled as moral laws and regulate both the human interactions and the life of the soul. Importantly, under the general SD tenets, selfishness is seen as the worst human beings' flaw. The Spirits' Book by Allan Kardec examined exhaustively this aspect, for example, in the question 913:

Which, among the vices, may be regarded as the root of the others?

Selfishness, as we have repeatedly told you; for it is from selfishness that everything evil proceeds. Study all the vices, and you will see that selfishness is at the bottom of them all. Combat them as you will, you will never succeed in extirpating them until attacking the evil in its root, you have destroyed the selfishness which is their cause. Let all your efforts tend to this end; for selfishness is the veritable social gangrene. Whoever would make, even in his earthly life, some approach towards moral excellence, must root out every selfish feeling from his heart, for selfishness is incompatible with justice, love, and charity; it neutralizes every good quality. (Kardec, 1857/2003a, p. 362) [4].

In essence, spirituality may encapsulate a personal belief system, as proposed by Javaheri et al. (2013). As such, it gives rise to a transcendent relationship with God or a higher power by finding purpose and value to our lives. Evinced the relevance of spirituality as a construct through scholarly work and SD's religious tenets, it is timely to ascertain what implies gathering SC. In this regard, the Table 1 presents some definitions identified through the literature review. Although the overwhelming majority of them are derived from conceptual work, it allows us to frame the theoretical frontiers of SC.

\section{Key elements of spiritual capital}

A thematic analysis of the key elements approached in the definitions of SC revealed at least six salient features, namely: wealth, faith and belief, values, virtues, vision and benefits thereof. Overall, they form a broader view about SC really entails. In this regard, these key ideas are discussed below, particularly from the workplace spirituality theory and SD's perspectives.

Wealth. Thaker (2009) suggested that the wealth creation is derived from three forms, namely, social, environment and economic, which is commonly translated into the so-called triple bottom line or people, planet and profit. However, such a reasoning disregards the spiritual element whose benefits and relevance were pointed out above. An examination of the definitions of SC reveals that the notion of wealth is not put aside (Zohar and Marshall, 2004; Zohar, 2010). In fact, Zohar and Marshall (2004) wisely recognized that SC provides a sort of "wealth that enriches the deeper aspects of our lives" (p. 3). Such wealth should be amassed since from the day one that of our conscience awake in this corporeal existence. Additionally, one must keep in mind that the spiritual wealth is not an easy asset to accumulate, but it may be apparently the only wealth that really matter to us. In fact, Kardec (1866/2003b) found that the humankind is forced to leave all material possessions in this corporeal dimension. Rather, all worldly assets belong to us only temporarily to our usage. Put another way, we have no real ownership of any earthly asset. In light of it, he inferred that our true assets are essentially intelligence, knowledge and moral qualities, i.e. our true wealth (SC). Therefore, these capabilities will be determinant to our future. Under such a perspective, we should then improve and refine them as much as possible because, on the whole, they represent our $\mathrm{SC}$, and in this will reside our happiness or unhappiness in the spiritual dimension as well as in the future corporeal existences. 


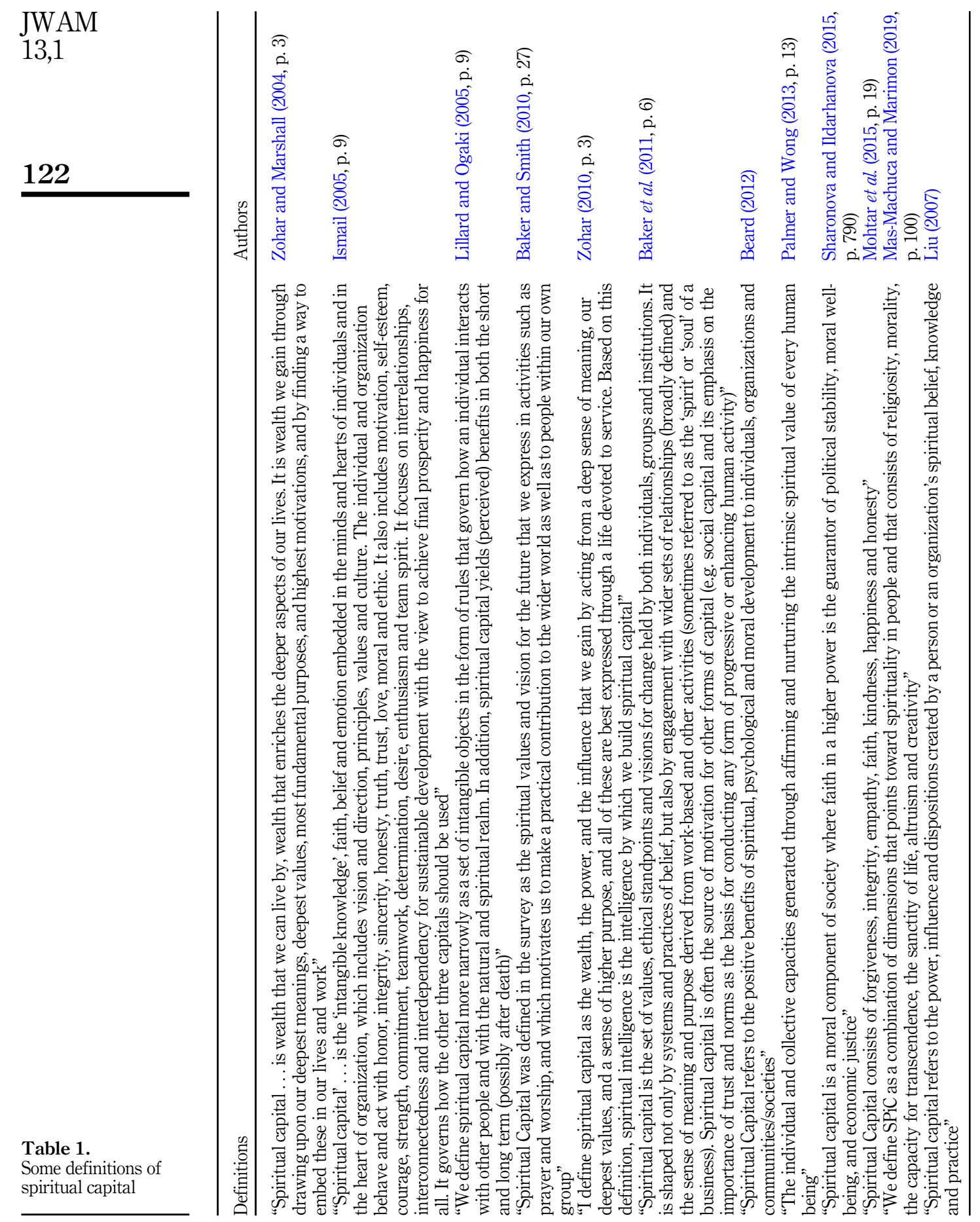


In a similar fashion, it is worth mentioning some spiritual messages from the Spirit Emmanuel, psychographed by the medium Francisco Cândido Xavier, which touched in this matter (Xavier, 1949/2006):

It is only this spiritual richness, which is acquired in situation of laborious work, deep understanding, overcoming ones' self and an incessant effort, will grant the Spirit a position of a genuine elevation and a permanent well-being beyond the transformation imposed by physical death. Such achievement will only be effective when the Spirit gives itself totally to the Father for the greatness of the Divine Service. (p. 290; see also Vasconcelos, 2010, for a comprehensive discussion on this topic)

In addition, the same spiritual entity also added:

Notwithstanding, when... [the people] used their possibilities to do the work of goodness without selfishness, acting out of self-interest and leaving aside their personal whims, then they will be able to prioritize the purpose of God's work. By doing so, and also struggling, loving, suffering, giving themselves to him, they will certainly acquire the eternal and non-transferable gold [the spiritual capital]. (p. 290)

Spiritual Doctrine adherents allude to the Jesus Christ's teaching on this topic through which he warned the perils of handling improperly the earthly wealth: "Then Jesus said to His disciples, Assuredly, I say to you that it is hard for a rich man to enter the kingdom of heaven" (Jesus - Matthew 19:23; New King James Version). Furthermore, in other part of the Gospel, Jesus referred to the challenge surround this issue, particularly to those people excessively devoted to gathering material assets: "And again I say to you, it is easier for a camel to go through the eye of a needle than for a rich man to enter the kingdom of God." (Jesus - Matthew 19:24; New King James Version). Similarly, the Apostle Paul, undoubtedly a prominent character in terms of the Christian's faith, noted that "For the love of money is a root of all kinds of evil, for which some have strayed from the faith in their greediness, and pierced themselves through with many sorrows" (1 Timothy 6:10; New King James Version). Overall, SC involves garnering an invisible resource, which is by all means highly valued to God's eyes.

Faith and belief. Other key components underscored by the definitions of SC are the issues of faith and belief (Liu, 2007; Ismail, 2005; Baker et al., 2011; Mohtar et al., 2015). By and large, spiritual theme presupposes a strong belief in something ethereal, which is not easily touched or seen. For these reasons, spiritual progress is rightly seen as inner conquests, which are stored in our souls. Definitively, these are the treasures of our SC. As a consequence, materialist and atheist individuals have considerable difficult to accept it. Their excessive belief in tangible things impedes them to see above and beyond. Either way, some scholars have framed faith in a very insightful manner. For example, Fry (2003) noted that "Faith is more than hope or the expectation of something desired. It is the conviction that a thing unproved by physical evidence is true" (p. 713, italics added). Caldwell et al. (2009, p. 104) suggested that faith is related to "behaviors and actions of an individual" in which he/she gives up his/her personal desires and power to God based on the hope that those actions will "comply with God's will". In turn, Hoffman and McNulty (2012) argued that faith is "the glue that adds coherence to our otherwise fragmented bits of information we carry in our minds" (p. 221).

In a related vein, SD also presents a very intriguing view about this matter. Drawing on Jesus Christ's teachings, Kardec (1866/2003b) proposed that:

(...) The mountains which faith can transport are the difficulties, the resistances, the ill will, in fact all those things which Man has to face, even when we refer to good things. (...) Robust faith gives perseverance, energy and resources which allow us to overcome these obstacles, be they large or small (...). (p. 201)

Exploring more transcendent lens, Kardec (1866/2003b) stated that: 
JWAM

13,1

True faith is linked to humility; those who have it, deposit more confidence in God than in themselves, as they know they are but simple instruments of Divine Purpose and can do nothing without God. This is the reason why the good Spirits come to their aid. (p. 202)

Going further, Kardec (1866/2003b) also warned about the danger of cultivating a blind faith, which leads to the fanaticism by disregarding the evidence and reason. In this way, he argued that:

Rationalized faith, when based on facts and logic, leaves no doubts. Then the person believes because they are certain; and no one can be certain unless they understand. This is why they are unshakable, because unshakable faith is that which can stand face to face with reason in all epochs of humanity. (p. 203)

Values. In parallel, the construct of values is equally evinced by many authors (Zohar and Marshall, 2004; Ismail, 2005; Baker and Smith, 2010; Zohar, 2010; Baker et al., 2011). In a nutshell, one can state that values express what we really possess in our intimacy. Values are the by-product of our personality and when we see, for example, a politician that distorts facts in order to benefit himself or a manager telling lies, we have no doubts about the kind of "values" they embrace. Therefore, values per se are qualities that we develop in ourselves and they are essential to build a SC. Ideally, we must consciously strive for encompassing more superior values in our behavior and actions. Accordingly, more spiritually-oriented workers tend to show higher values in performing their work and duties. In this sense, a phenomenological study identified that they usually have a sense of pride in their work; are honest and caring with internal and external clients, customers, co-workers as well as everyone around; conscious of other co-workers; adaptable; responsible; non-confrontational; cooperative when needed; believe in God or a higher power; driven to create and experience a sense of meaning; driven to balance and interlink both family and work; try to be fair and genuine, independent of the leadership line of thought or the organizational philosophy and are willing to help when and wherever, even if necessary (Marques, 2006).

Other related study by Marques et al. (2007) found that workplace spirituality is intertwined with values and positive features such as trust, openness, kindness (compassion and friendship), honesty, moral and ethics, a sense of peace and harmony, aesthetically pleasing work environment, team orientation, understanding, faith in God, respect and truth. Whereas Vasconcelos' (2013) findings expanded such list by identifying the following themes: fun, love, well-being, a sense of religiosity, serenity, social responsibility, tolerance, sincerity, meaning of work, higher values, human valuing, coherent attitudes, common interests and objectives, politeness, willing to offer guidance and be an example, stimulating environment, listening to and be listened, praying habit, patience, positive energies and thoughts, concerns with other's well-being and the spirit of solidarity. In turn, Crossman's (2015) investigation also added values like empathy, caring and a sense of connectedness. In sum, it appears that values create a motivational force that gears the individual toward a range of experiences that enable character strengths and virtues (Crossman et al., 2013).

At first glance, SD literature seems to encapsulate the sensitive issue of values through two Gospel's teachings, namely, "Therefore, whatever you want men to do to you, do also to them, for this is the Law and the Prophets" (Matthew, 7: 12; New King James Version). Similarly, the same concern is addressed in Luke's Gospel: "And just as you want men to do to you, you also do to them likewise” (Luke, 6: 31; New King James Version). Kardec (1866/2003b, p. 116) expanded the analysis on this matter by noting that this is a core guideline toward our interplays with others. In his view, this tenet is conducive to "the destruction of selfishness". Still to him, when we assimilate such a recommendation as a rule then "as the base of all institutions, then man will understand true fraternity, and so make it possible for peace and justice to reign on this planet” (p. 116). 
Virtues. As expected, authors describe a lot of features and elements that take part of a broader virtue framework. As rightly pointed out by Malloch (2010), "Exactly like St Paul's fruits of the spirit, the fruits of spiritual capital are the virtues" (p. 756). It is a hard task to display a virtuous behavior, given that it implies a deepest change. Definitively, we do not live in a virtuous society; otherwise, we would have ever reached better outcomes to everyone. Therefore, we have to keep in mind that we will certainly tackle problems by simply having the courage to follow a virtuous path. The humankind history has extensively shown the cost of embracing it. Seen in this way, "Virtues are moral ideals that we should aim to attain even if we are unsuccessful” (Alzola, 2012, p. 379).

Anyway, we will not be able to gather a SC without the assimilation of virtues. On the whole, scholars have provided rich opinions and perceptions about this topic that deserves to be highlighted for the purposes of this work. For example, Rozuel and Kakabadse (2010) pointed out that a virtuousness frame requires alignment between our actions and character. Hartman (2011) suggested that "Virtue is intrinsically good for the virtuous soul" (p. 7). In fact, a vicious individual certainly does not value enough the benefits of adopting a virtuous behavior. In reality, virtues should be embraced for us regardless of the direct or indirect benefits to our family, friends, fellows or ourselves. A myriad of qualities has been described as belonging to the virtue sphere such as justness, generosity, kindness, moderation, loyalty, flexibility and reliability (Ketola, 2006).

Conceptually, virtue is also associated with integrity, discernment, love, respect, humility, diligence, temperance and courage (Lanctot and Irving, 2010). On the other hand, Audi (2012) alluded to virtue as a worthy trait of character capable to influence our conduct. In addition, it nurtures their possessors with good reasons to apply in any context, that is, action and motivation to do them. In the context of work, Alzola (2012) proposed that business leaders have the duty of behaving virtuously, as well as creating "opportunities for the development and the expression of the virtues" (p. 394). In a related vein, it is believed that a virtue frame "enables a person to do certain things by removing any internal obstacles the person has that prevent the performance of virtuous actions; a virtue motivates a person to perform particular actions by influencing their desires, preferences, wishes and goals" (De Bruin, 2013, p. 586). Similarly, to Bright et al. (2014) virtuous individuals put into practice certain mindsets, intentions and behavior that are aligned with the goodness. Furthermore, these individuals are prone to search for a meaningful life and positive human impact.

To SD, virtues are rooted in the challenge for us to be perfect as God. Spiritual Doctrine adherents understand that Jesus Christ was very accurate to recommend us to pursue it. Allan Kardec (1857/2003a, p. 365, 1866/2003b, pp. 180-181) construed such idea through the features of "the good person", that is, his findings revealed what meant to be virtuous individuals. Rather, he found that such people would exhibit a range of good features such as complying with the laws of justice, love and charity in their highest degree of purity; examining their conscience concerning their own actions in light of those laws; doing to others everything that they would like to be done to themselves; having their faith in God, in his goodness, in his justice and in his wisdom; having faith in the future, i.e. to put spiritual possessions before those of a temporary nature; possessing the sentiments of charity and love do good for the sake of goodness, without waiting for payment of any kind; enjoying satisfaction in the benefits they are able to spread, in the service they are able to render, in the happiness they promote, in the tears they are able to dry, and in the consolation they offer to those who are afflicted; being always good, humane and benevolent with everyone, without any distinction as to race or creed, because they see all men and women as brothers and sisters; being driven by charity in every circumstance; avoiding rancor, hate and desire of vengeance; being indulgent with the weaknesses of others; studying their own imperfections and working unceasingly to combat them; and using their power to enhance the morale of the people and never to crush them with their own pride. 
JWAM

13,1

Vision. The concern to create a vision or take part of a compelling one appeared in some definitions of SC (Ismail, 2005; Baker and Smith, 2010; Baker et al., 2011). A good vision has the power to integrate good aspirations, purposes and wishes into the same frame. A good vision is attractive because it joins the scattered individual perceptions toward the same goal. Our planet and institutions need desperately of good visions in order to shape more healthy and happy human conditions. This era of chaos also offers a great opportunity to us to definitely internalize the cosmic and spiritual realities. Alternatively, Howard and Welbourn (2004) suggested that "This is a time of searching for a larger, nobler vision to sustain our efforts and engage our souls" (p. 1). Undeniably, this is a special moment to think out of the box and enlarge our perceptions in relation to the transcendental knowledge. After all, the value and relevance of a good vision may mold our everyday behavior to embrace the responsibility to do always right, make good and be spiritually-driven. Put another way, a good vision may ignite our interest and efforts toward pursuing the SC. The role of the organizational leadership is fundamentally to create a worthy vision (e.g. Fry, 2003, 2005; McGee and Delbecq, 2003; Fry et al., 2011), particularly a shared vision that engages everyone (Kouzes and Posner, 2009). An ideal vision should possess at least six features, namely, be powerful, purposeful, self-determining, concrete, multi-faced and emotional (Clayton, 1997, as cited in Brătianu and Bălănescu, 2008, p. 21).

Meanwhile, the SD tenets depict new frontiers and understandings about the implications of spiritual reality. More specifically, it offers an exciting vision that may transform our life interests in more than just the pursuing of earthly assets as follows:

7. Spiritism opens up and broadens out the thought process, so offering new horizons. In place of a short-sighted vision concentrated only on the present, which makes this fleeting moment passed on Earth the unique and fragile axis of the eternal future; Spiritism shows us that this life is nothing more than a link in the magnificent, harmonious assembly which is God's work. It also shows us the solidarity which joins together all the different existences of one being, of all beings of the same world, and all the beings of all the worlds. It offers the base and the reason for universal fraternity... (Kardec, 1866/2003b, p. 34)

Benefits. The last important aspect identified in the definitions of SC involves the issue of benefits (Lillard and Ogaki, 2005; Beard, 2012). Interestingly, Lillard and Ogaki (2005) surmised that they be enjoyed after death. Such a conjecture dovetails perfectly in the SD tenets unfolded by Kardec's findings. Nevertheless, King (2008) believes that more findings will help "to promote personal and social well-being in all areas of human life" (p. 182). Stead and Stead (2014) bluntly suggested that SC "helps to create a sustainable world while nourishing and sustaining the human spirit” (p. 151). For now, it seems reasonable to take into account what similar theories have identified or added to the understanding of SC, particularly workplace spirituality and spiritual leadership literatures (Middlebrooks and Noghiu, 2010).

Accordingly, workplace spirituality theorists have fared well in identifying what kind of benefits is yielded by the belief on the spiritual power. In this regard, it is worth remembering that spirituality in the workplace is associated with better productivity; valued employees; more positive working conditions; job satisfaction; organizational commitment; purpose and meaning driven organizations; integrity, honesty, love, hope, kindness, respect and nurturing managers; sense of community; sense of belonging in the workers; empowering, delegation and cooperation; and improvement in morale and loyalty (Altaf and Awan, 2011; Marschke et al., 2011). To Chawla and Guda (2010), workplace spirituality "induces or helps employees ... to transcend their narrow or economic self-interests for others, and therefore these employees (or salespersons) will conduct with customers in a manner that goes beyond their immediate or economic self-interests" (p. 70). 
Otherwise, SD alludes to a future reward, that is, the spiritual life. Rather, a spiritual message by the spirit John reflected such a perception as follows:

Everyone can give! Whatever your social standing you will always find something to share with another. From whatever it is that God has bestowed upon you, a part of what He has awarded is owed to those who lack the necessities of life, seeing that, in their place you would wish others to share with you. Perhaps your earthly treasures will be a little less. Nevertheless, your heavenly treasures will likewise be increased. It is there, in heaven, that you will reap a hundredfold of all that you have sown as benefits to others in this world. (as cited in Kardec, 1866/2003b, p. 147, italics added).

Individual spiritual capital

Therefore, this suggests that all goodness that we put into practice will be amount to our personal SC. Indeed, we have ample opportunities to do good in all walks of life, including at work settings where we usually spend great part of our daily routines. Thus, one may infer that by doing good we will create our happiness. Put differently, we should take into account that:

Spiritism, in accordance with the express teachings of the Gospel, with reason, and with justice, shows us that each soul is the artisan of its fortunes, both during life and after death; that it owes its progress and happiness to its own efforts, and not to any favoritism; that God rewards its endeavors to advance in the path of progress, and punishes its negligence as it continues to be negligent. (Kardec, 1878/2005, p. 73)

In essence and building on Baker et al.'s $(2011$, p. 6) definition, an individual really interested in building a SC must be willing to find a sense of meaning and purpose in his/her life and work activities. Additionally, he/she must behave in accordance with superior values, beliefs and ethical behavior in order to engage in positive relationships and human enhancement.

\section{A conceptual model}

The SC theme has been received little theoretical conceptualizations from scholars. For instance, Middlebrooks and Noghiu (2010) approached the issue of SC through the lens of service. But that work attributed a great weight to the construct of service in detriment to SC. In other words, SC antecedents and its impact were not properly explored. With this caveat in mind, it appears to be vital to enrich a workable model with such concerns. In contrast, Kolade and Egbetokun's (2018) model depicts a more elaborated conceptual framework of SC. Rather, they focus on facing turbulent times through SC. By the way, this model suggests the construct of prayer, meditation and group reinforcement as sources of SC, but such constructs are usually seen as copying transcendental mechanisms. Seen in this way, they may eventually help maximize - likely performing the role of moderators or mediators - the antecedents of SC, that is, variables that allow us to garner this valuable intangible asset.

Broadly speaking, SC literature does not focus on the nitty-gritty of a model capable to build it, not mention the real possibility of being measured. In light of it, this paper suggests to fulfill this theoretical gap through the proposition of some constructs that may allow the individual to draw on his/her inner strengths and capabilities, enable positive feelings and states, and engage even more in meaningful tasks (see Figure 1). In essence, some constructs that lead a person to reach a self-improvement, a spiritual development, a transcendental knowledge or perception to handle the corporate life in a smarter manner. In a related vein, the Spirit Emmanuel noted that:

Life is an advanced course on improving oneself through effort and struggle. If the stone itself must go through the polishing process in order to reflect the light, then what about we, who have been called to exteriorize the divine resources? (Xavier 1956/2013, p. 121).

Further, this spiritual entity suggests that it is everyone's obligation the task of self-improvement (Xavier, 1956/2013). Therefore, this path appears to be determinant to 


\section{JWAM}

13,1

\section{8}

Figure 1.

Conceptual model of spiritual capital

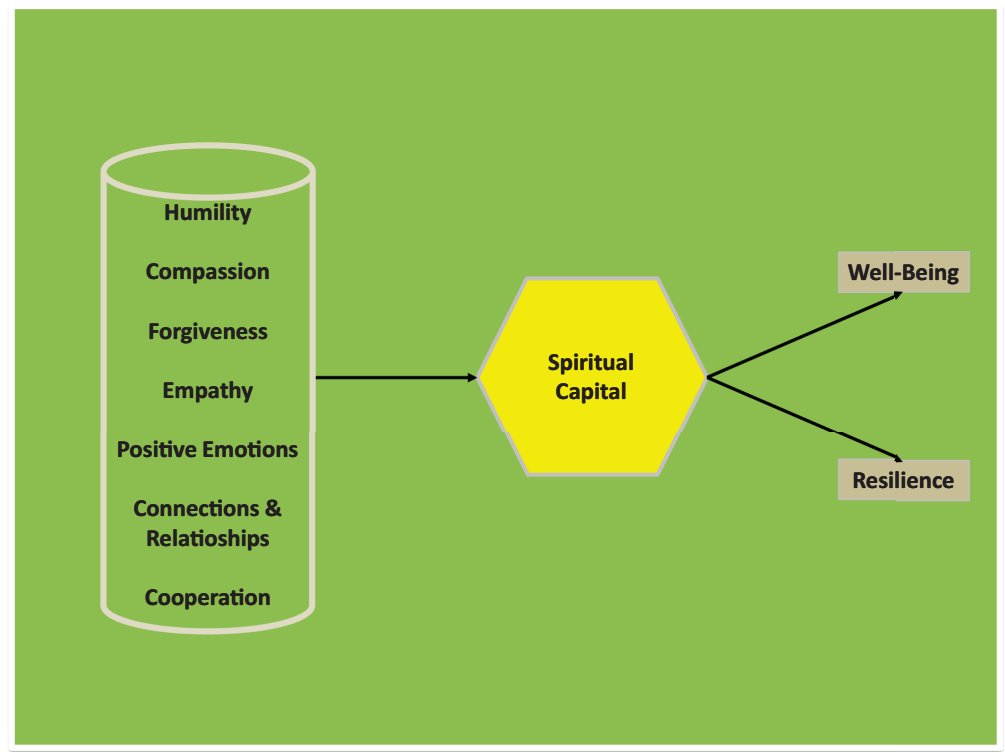

uplift a SC. Furthermore, the antecedents of SC must be necessarily made of variables that express some sort of virtues. Given its features, the construction of SC is likely addressed by individuals that are really concerned with these issues. With this in mind, it does not appear to be logic that materialistic-oriented individuals nurture such a concern. Premised on this understanding, the antecedents of SC must be strongly intertwined with the demonstration and supporting of virtues and values. In this way, it is pertinent to remember that highly spiritually-driven individuals such as Jesus Christ, Mahatma Gandy, Buda and Saint Francis possessed an abundant repertoire of moral agency. Moreover, the virtue of humility was the hallmark of these characters.

\section{Antecedents}

Humility. In light of it, humility capability may be deemed as a suitable starting point to one's build a SC. To a large degree, humble individuals have an accurate opinion about their strengths, capabilities and limits. In general, they do not attribute values and features that they do not possess. In a nutshell, they have a clear picture about themselves. Key elements associated with humility include: an accurate assessment of one's abilities and achievements (definitively, this is not mean low self-esteem or self-deprecation); disposition to acknowledge one's mistakes, imperfections, gaps in knowledge and limitations; openness to new idea and contradictory information; seeing oneself as just one person in the larger scheme of things; a relatively low self-focus by embracing the posture of "forgetting of the self", while recognizing to be part of the larger universe; and an appreciation of the value of all things (Tangney, 2005, p. 413). In work settings, humility enables a person carries out more precise analysis of his/her strengths, weakness, opportunities and threats, that is, intrapersonal resources. In addition, humility is seen as a pro-social quality that may lead to good citizenship behaviors like cooperation and helping. Overall, it is expected to be found more in followers rather than leaders (Owens et al., 2012). Nevertheless, humility has been positively linked with many aspects of leadership in corporate life (e.g. Frostenson, 2016; Caldwell et al., 2017; Kruse et al., 2017). Therefore, one may elicit from this discussion the following: 
Proposition 1. The commitment to embracing the virtue of humility will likely lead the individual to build a spiritual capital.

Individual spiritual capital

Compassion. The adoption of a compassionate behavior denotes respect for others, as well as creating an organizational climate in which one stimulates others to be equally compassionate toward us (Lennick and Kiel, 2005). After all, as morally imperfect human beings, we all are subject to engaging in wrongdoings, making bad decisions or behaving unwisely. SD tenets draw on the delicate Jesus Christ's teaching that urges us to be compassionates: "He who is without sin among you, let him throw a stone at her first" (John, 8: 7; New King James Version). To Allan Kardec (1866/2003b), "The most appropriate sentiment for making mankind progress, by dominating his selfishness and pride, which predisposes the soul towards humility, beneficence and the loving of one another, is compassion!" (p. 148). Compassion is regarded as a vital virtue toward achieving noble goals. In addition, compassion gives us the capability of understanding "other's suffering and motivates us to put an end to cruelty, envy, greed, pride, and hatred" (Thaker, 2009, p. 190). Seen in this way, compassion sensitizes people to fight against "unjust and oppressive social structures" (Dyck and Schroeder, 2005, p. 725). A notion of practical compassion put limits in the self-interest in order to encompass the common good. In addition, it is rightly acknowledged that organizations can be viewed as tools for enabling practical compassion (Lips-Wiersma and Nilakant, 2008). Overall, researchers have identified that the experience of compassion has added very positive feelings and outcomes to both employees and organizations likewise (Dutton et al., 2007; George, 2014; Aboul-Ela, 2017). In light of it, the following proposition is offered:

Proposition 2. The commitment to embracing the virtue of compassion will likely lead the individual to build a spiritual capital.

Forgiveness. The need of practicing forgiveness lies in the core of the majority of religion principles and such an understanding is not different for SD. In this regard, a message from the spirit Emmanuel, related to the Gospel's teachings (i.e. Matthew, 18: 33 and 6: 14-15) [5], [6], warned us that:

If the task presents itself with obstacles, then remember the innumerable times that the Christ has had mercy on your spirit. This attenuates the darkness of the heart, Observe, in each companion of struggle, a blessing and an opportunity of fulfilling the divine plan about your existence. (Xavier, 1949/2006, p. 60)

This suggests that we have been target of forgiveness from the spiritual world without we know it. Such benevolence should not surprise us regarding that we are moral imperfect souls. Then if we are systematically making mistakes throughout our lives and we are being forgiven by God, why we do not consider granting the same possibility to others? What do impede us to equally forgive our neighbor? Therefore, one may infer from this discussion that what really matter is that acquiring the capacity of forgiveness is undoubtedly a remarkable spiritual feat. Nevertheless, scholars recognized that forgiveness is a poorly understood virtue and one of the most difficult to achieve (e.g. Cameron and Caza, 2002). In fact, one may suspect that our civilization has great difficult to accept forgiveness as a spiritual resource to one's transformation. Nonetheless, by forgiving others we are freeing them from the burden of past mistakes, as well as allowing them a chance to begin anew (Caldwell and Dixon, 2010). Overall, forgiveness appears to positively impact the general well-being of individuals (Cameron and Caza, 2002; Worthington et al., 2005; Barclay and Saldanha, 2016). Also noteworthy is that "without a tolerance for mistakes and the knowledge of our imperfection, we are likely to be rigid, inflexible and unable to engage with others in ways that promote our mutual good" (Lennick and Kiel, 2005, p. 7). Based on the arguments above, one may propose the following: 
JWAM

13,1

130
Proposition 3. The commitment to embracing the virtue of forgiveness will likely lead the individual to build a spiritual capital.

Empathy. This is one of the most notable qualities to an individual portrays in this ruthless world in which we live in. The ability to put ourselves in other shoes is not commonly noticeable. Regrettably, the selfish human proclivity to focus on its exclusive problems does not allow seeing the real malaises and depressive pictures that abound everywhere. For the sake of it, it is vital that human beings integrate into their souls the ability of acting empathetically. In effect, one cannot envisage a robust SC without such a virtue. Empathy is defined as the "remarkable capacity we humans have to experience what other people are feeling, to imagine ourselves in another's psychological place and feel his or her joys and sorrows as if they were our own" (Schulman, 2005, p. 501, italics in the original). Accordingly, it culminated to be regarded as a "source of moral motivation", given that empathy may lead to the implementation of altruistic acts (Schulman, 2005). The capability of knowing what someone else is feeling is paramount to human interactions (Decety and Lamm, 2006).

Empathetic people tend to mitigate the tensions and injustice in all levels of life. Seemingly, an empathetic individual enjoys a healthier lifestyle and enacts positive relationships (Natale and Sora, 2010). In addition, it appears that empathy can be employed in ethical managerial action involving dilemma situations, particularly in those ones that affect the well-being of the organization and the other stakeholders (Dietz and Kleinlogel, 2014). On the surface, empathic managers benefit their employees in a direct and indirect manner (Scott et al., 2010). Surprisingly, empirical evidence suggested that business students and business leaders displayed lower degrees of empathy (Holt and Marques, 2012). On the whole, the insights above addressed allow us to propose:

Proposition 4. The commitment to embracing the virtue of empathy will likely lead the individual to build a spiritual capital.

Positive emotions. It is also expected that spiritually-driven individuals cultivate positive emotions in their interactions with workmates. Nonetheless, this is an uncommon feature within the workplaces, given that organizations are prone to shelter toxic emotions due to a myriad of reasons. Even so, people who are capable of showing such a capacity are highly praiseworthy. Positive emotions help mitigate the harshness and frustrations of corporate life. In fact, it is believed that religious and spiritual workers likely have a set of positive motions such as compassion, empathy, love and understanding that may reduce the emotional stress in the workplaces (Byrne et al., 2011). To a large extent, positive emotions encapsulate an array of benefits suitable to use at work settings.

For example, by experiencing positive emotions individuals may transform themselves to become more creative, connected, resilient and healthier (Simmons and Nelson, 2007). Furthermore, positive emotional experiences in the workplaces will likely yield results that enhance the spirals of growth, as well as reverberating outside of the organization (Sekerka and Fredrickson, 2008). In addition, positive emotions may provide resiliency in times of difficulty to people tackle the challenges (Sekerka et al., 2012). In light of it, Fredrickson (2005) suggested that:

We should cultivate positive emotions in our own lives and in the lives of those around us not just because doing so makes us feel good in the moment but also because doing so will transform us to be better people, with better lives in the future. (p. 131).

In turn, SD literature points out the need for learning to regulate our emotions in such a way that only positive ones may come up in any circumstance. Taken together, the arguments aforementioned lead us to suggest the following: 
Proposition 5. The commitment to showing only positive emotions will likely lead the individual to build a spiritual capital.

Connections \& relationships. Also relevant in the search for building a SC is our commitment to engaging in meaningful and positive interactions with others. A popular dictum states that "We serve God by serving others". Our neighbor (the other) is always our best reference to enhance our own spirituality. Jesus Christ was absolutely clear about such imperative when he proclaimed the second commandment: And the second, like $i t$, is this: "You shall love your neighbor as yourself." (Mark, 12: 31; New King James Version). Therefore, we can add a valuable merit to our own spirituality by respecting our neighbor. As noted by Johnson (2009), good connections cannot be developed unless we take into account the well-being of others and, particularly in the workplaces, treat our colleagues with compassion and respect. Nonetheless, building good relationships and connections are sometimes daunting. Human beings are highly complex entities that carry inside them a range of idiosyncratic values and opinions. Otherwise, corrosive connections tend to lead people to be devalued and disrespected, and this undermines the feelings of self-esteem. Such experiences generate strain and erode people's emotional and cognitive capacity to function well (Dutton, 2003).

Cultivating high-quality relationships at work is essential to create a positive climate that benefit all organizational members and ultimately the company (Brueller and Carmeli, 2011; Carmeli et al., 2013; Caillier, 2017; Vasconcelos, 2017b; Tran et al., 2018). Evidence also suggests that high-quality relationships of shared goals, shared knowledge and mutual respect positive influence employees to perform their work. In addition, it also provides them the opportunity to learn from eventual mistakes and failures (Carmeli and Gitell, 2009). In light of it, one may infer that:

Proposition 6. The commitment to cultivating high quality connections and relationships in the workplace will likely lead the individual to build a spiritual capital.

Sense of cooperation. The last envisioned construct in our conceptual model is the sense of cooperation. After all, such a capacity is pivotal in any human endeavor and when properly used it can contribute to outstanding outcomes. In the spiritual domain, Kardec's (1857/2003a) findings identified that the good spirits intensively cooperate with God by performing distinct activities and missions. Overall, they are highly engaged in the task of helping the incarnated ones (i.e. us) to make good and reach a spiritual development as well. Corroborating such a view, the spirit Emmanuel remarked: "In the smallest experiences, such as at work or play, in the home or out on the street, he [Jesus] is there, inviting us to constantly practice the Good" (Xavier, 1956/2013, p. 326). Thus, the imperative of cooperation permeates all human efforts toward the progress, including the spiritual.

In this regard, scholars noted: "Positive emotions appear to transform cooperative dynamics because they broaden and build people's habitual modes of thinking, and in so doing make relationships and people more flexible, empathic, and creative" (Cooperrider et al., 2007, p. 427). Similarly, Krahnke and Cooperrider (2008) argued that our future lies in the collaborative capacity, that is, a future that supports rich and diverse life on the planet and also encourages the thriving of human spirit. Further, by working on a collective effort and using positive experiences as drivers for development, one may enable the creative thinking necessary to engender an innovative future (Sekerka et al., 2012). Based on these perceptions, it is suggested that:

Proposition 7. The commitment to cooperating in the workplace will likely lead the individual to build a spiritual capital. 
JWAM

13,1

\section{Potential outcomes}

At this point, it is pertinent to consider the potential effects of cultivating virtues, inner capacities and forming a SC. Regarding the personal sacrifices that an individual certainly make to reach such a stage, one may surmise whether all this effort is worth. Arguably, the answer will be affirmative since the individual really places spiritual values at the core of his/ her life. In fact, spirituality, positive behavior, held values, being engaged in doing good and in meaningful work tend to trigger inner peace and personal satisfaction in the adherent of such repertoire. I advocate that the search for building a SC - including, broadly speaking, the dimension of work (i.e. a high quality work, productivity, engagement, commitment, ethical behavior, positive leadership, doing good and relationships) - yields positive states and feelings. Additionally, this is a special moment for us to put aside at least partially material concerns. In this sense, Kardec (1868/2003c) noted that:

14. Humanity is becoming adult. With new needs, more elevated and larger aspirations, it comprehends the emptiness of the ideas with which it has been fed and the insufficiency of its institutions for its well-being. It finds no more, in the existing state of things, the legitimate satisfactions to which it has been called (...). (p. 218)

Well-being. In this regard, it is worth pointing out that the subjective well-being is a seen as an umbrella concept that encompasses other constructs such as an overall evaluation or global judgment of life satisfaction, affective experiences and a belief component (Weiss, 2002). In turn, Giacalone and Prosmilo (2010) define "well-being as the extent to which an individual is satisfied with his/her life, experiences a preponderance of positive affect, and possesses a healthy body and mind" (p. 276). Other authors suggested that the well-being is rooted in psychological, physical and social core dimensions (Grant et al., 2007). And when people are feeling good, they are expressing, indeed, a sense of psychological well-being (Robertson and Tinline, 2008). Although spirituality is not clearly associated with well-being (cf. Baptiste, 2009; Dagenais-Desmarais and Savoie, 2012), it is highly likely that it also may produce such a state, especially when the individual exhibits values and virtues at work, as well as demonstrating to pursue noble goals. Accordingly, one may infer that:

Proposition 8. The search for building a spiritual capital positively influences one's well-being.

Resilience. In parallel, one cannot assume that the simple disposition to be a better citizen or seek to make things right would produce achievements without pain and disappointments. Frankly, it will be naive to believe so. After all, human journey clearly shows that the overwhelming majority of the good doers faced many hurdles and shadows in their paths. Worse still, many of them were victims of incomprehension, brutality and even murder. By the way, SD offers insightful explanations about such conundrums that are worthy of being highlighted. In this regard, Kardec (1878/2005) remarked that:

(. . .) The troubles of human life are so many lessons for the soul; lessons often hard to bear, but that are all the more profitable for its future, in proportion to the depth of the impression left by them: they give rise to incessant struggles that develop its moral and intellectual faculties and strengthen it in the pursuit of goodness, and from which it always emerges victorious, if it has had the courage to persevere in its efforts to the end. It reaps the reward of its victory in the spirit-life... (p. 57)

Thus, the effort to obtain our own light (spirituality) demands great determination. In other words, I suggest that the endeavor of building a SC creates more capacity of resilience. The inclusion of this construct lies in the fact that it is seen as the most important positive resource to handle today's turbulent and stressful workplaces (Avey et al., 2009). Resilience at work involves behavioral, affective and psychological manifestations of positive adaptation and professional growth in face of significant adversity at work (Caza and Milton, 2012). 
Nowadays resilience is important not only for personal and job effectiveness but to all life aspects likewise (Kossek and Perrigino, 2016). Recent literature review indicated that the conceptualization and operationalization of resilience have been quite varied (Linnenluecke, 2017). Accordingly, it appears to be feasible to frame resilience as one of key variables in the context of spirituality, particularly in terms of outcomes. In light of this understanding, I propose the following:

Proposition 9. The search for building a spiritual capital positively influences one's resilience.

\section{Conclusions and implications}

By bringing the conceptual framework of SC to the forefront of management, spirituality and religion studies through an interdisciplinary approach showed that it is not an elusive or mythical topic. On the contrary, my analysis revealed that this is a serious and surprisingly neglected issue that deserves further attention in light of the benefits that it can potentially yield. In fact, evidence indicates that spirituality still does not belong to the mainstream, as well as its related constructs. Perhaps this fact helps account for why the topic of SC continues to be understudied. Given its intangible nature, SC appears to provide exclusively ethereal gains and inner satisfaction. In other words, there is no indication suggesting any sort of earthy profit through the pursuing of SC. Focusing on such concerns denotes a clear desire to progress in other direction rather than the usual material one.

The literature of SC suggests that it may be built only through one's deep reflections and internal changes or, as the SD tenets propose, by means of inner reform. Certainly, SC is not going to be impactful unless the individual be willing to hold new values and interests. One may surmise that people less enthusiastic about spiritual matters will not likely strive to acquire a SC. In contrast, the idea of SC will likely reverberate in afterlife believers, spiritualoriented individuals and religious adherents. It appears that the learning about transcendental knowledge may gear a person toward the development of SC. Further, such efforts may help the individual to find out the spiritual reality. One may envisage that the pursuing of the SC may free people from the egocentric and selfish chains that rest inside them and guide their purposes toward a more genuine and superior goals.

Undeniably, SC is a topic that needs intense empirical and theoretical contributions. In this way, SC literature does not offer a consistent or flawless model capable of gathering a SC nor the potential results of it to the individual. Accordingly, the current paper tries to mitigate these deficiencies by depicting a conceptual paper. In essence, the model comprises some constructs that encourage people to use their inner strengths, capabilities, positive feelings, states and aspirations in order to engage even more in praiseworthy behavior and reach self-fulfilling. In a nutshell, it suggests going even further the customary life purposes at work. Consistent with the previous findings of positive psychology, positive organizational scholarship, workplace spirituality, psychology of religion and SD tenets, the conceptual model invites the individual to capitalize on salient virtues and remarkable human qualities so as to build a SC, namely: humility, compassion, forgiveness, empathy, positive emotions, connections/relationships and sense of cooperation. Finally, it is envisaged that the attempt to create a SC may lead the individual to a feeling of well-being and more resilience in life at work. Overall, this model appears to be fully workable and testable.

On one hand, the model may present more positive results, as noted earlier, in samples of religious and spiritually-driven people. Again, it is less likely that atheist or agnostic peopleregarding their usual views - may demonstrate interest in relation to SC. In addition, the research propositions may be explored in more specific studies. It is possible that more interesting insights may be derived from them. On the other hand, SC theory will likely be benefited from qualitative studies, especially those ones which are grounded on 
JWAM

13,1

134

phenomenological approach. Such empirical endeavors may certainly identify other relevant aspects missed here. Furthermore, future SC conceptual models may regard the constructs of kindness, helping behavior, patience and listening as potentially intervenient variables. Bearing in mind that the current conceptual model focuses exclusively on the individual stance, therefore, in this choice rests its major limit. Although SC is fundamentally associated with people, it is not unfeasible to elaborate a model devoted to the organizational level. In theory, spiritualized individuals tend to influence their organizations to be more spiritually based ones. Toward this end, distinct variables should be conceived such as the provision of employee's job satisfaction; engagement; work-family balance; the involvement in communities' matters; the practice of corporate social responsibility/citizenship behavior; the level of law-abiding (ethical behavior); organizational civility; customers' satisfaction; products complaint and so on. The careful selection of indicators related to these variables may theoretically show if an organization is adhering or not the goal of building a SC. Therefore, future studies should consider the possibility of exploring such theoretical avenues.

At last, the implications to develop a SC in the context of work are sizeable. After all, it implies to add more concerns to one's career much beyond those strictly functional or professional ones. Rather, it means to regard the work domain through unusual lens. Accordingly, SC brings the additional challenge to the individual acquiring0 spiritual literacy, superior values and virtues, that is, dimensions that are not easily obtained or developed without strong personal commitment.

\section{Notes}

1. The interested reader can find more information about the role performed by Allan Kardec (18041869) on the fundaments of SD, as well as his life and work, in the following websites: (1) https:// spiritisthouston.org/who-we-are/who-was-allan-kardec/; (2) http://ssbaltimore.org/allan-kardec/; (3) https://www.youtube.com/watch?v = Y1s91tLXLQw. Overall, the Spiritism Doctrine literature explains our origin, evolution and perspectives (see Vasconcelos, 2010).

2. Beyond a range of education and teaching books published by his real name, Hippolyte Léon Denizard Rivail (see, for a brief review, https:/en.wikipedia.org/wiki/Allan_Kardec), under the pseudonym of Allan Kardec, apparently in accordance with a spirit identified as Truth, was also the author of the so-called Pentateuch, i.e. five basic books focusing specifically on Spiritism doctrine, namely: The Book of Spirits (1857), The Mediums'Book (1861), The Gospel According to Spiritism (1864), Heaven and Hell (1865), and Genesis - The Miracles and Predictions According to Spiritism (1868). Noteworthy, he was the editor of the Spiritist Magazine - Journal of Psychological Studies and author of What is Spiritism (1859) as well.

3. I mean, "But lay up for yourselves treasures in heaven, where neither moth nor rust doth corrupt, and where thieves do not break through nor steal" (Jesus - Matthew, 6:20; New King James Version).

4. In the introduction of The Spirits' Book, Allan Kardec (1857/2003a) provided a historical summary about how the spiritual messages were conveyed. In addition, he claimed: "This book is a compilation of their teachings [the spirits]. It has been written by the order and under the dictation of spirits of high degree, for the purpose of establishing the bases of a rational philosophy, free from the influence of prejudices and of preconceived opinions. It contains nothing that is not the expression of their thought; nothing that has not been submitted to their approbation. (...)" (pp. 59-60, italics added).

5. "Should you not also have had compassion on your fellow servant, just as I had pity on you?" (Jesus Matthew, 18: 33; New King James Version).

6. "For if you forgive men their trespasses, your heavenly Father will also forgive you. But if you do not forgive men their trespasses, neither will your Father forgive your trespasses" (Jesus - Matthew, 6: 14-15; New King James Version). 


\section{References}

Aboul-Ela, G.M.B.E. (2017), "Reflections on workplace compassion and job performance", Journal of Human Values, Vol. 23 No. 3, pp. 234-243.

Altaf, A. and Awan, M.A. (2011), "Moderating affect of workplace spirituality on the relationship of job overload and job satisfaction", Journal of Business Ethics, Vol. 104 No. 1, pp. 93-99.

Alzola, M. (2012), “The possibility of virtue”, Business Ethics Quarterly, Vol. 22 No. 2, pp. 377-404.

Ashar, H. and Lane-Maher, M. (2004), "Success and spirituality in the new business paradigm", Journal of Management Inquiry, Vol. 13 No. 3, pp. 249-260.

Ashforth, B.E. and Pratt, M.G. (2003), "Institutionalized spirituality: an oxymoron?", in Giacalone, R.A. and Jurkiewicz, C.L. (Eds), Handbook of Workplace Spirituality and Organizational Performance, M. E. Sharpe, Armonk, NY, pp. 93-107.

Audi, R. (2012), "Virtue ethics as a resource in business", Business Ethics Quarterly, Vol. 22 No. 2, pp. 273-291.

Avey, J.B., Luthans, F. and Jensen, S.M. (2009), "Psychological capital: a positive resource for combating employee stress and turnover", Human Resource Management, Vol. 48 No. 5, pp. 677-693.

Ayios, A., Jeurissen, R., Manning, P. and Spence, L.J. (2014), "Social capital: a review from an ethics perspective", Business Ethics: A European Review, Vol. 23 No. 1, pp. 108-124.

Baker, C. and Smith, G. (2010), "Spiritual, religious and social capital - exploring their dimensions and their relationship with faith-based motivation and participation in UK civil society", Paper Presented at the BSA Sociology of Religion Group Conference, Edinburgh.

Baker, C., Stokes, P., Lichy, J., Atherton, J. and Moss, D. (2011), "Values, beliefs and attitudes in the era of late-capitalism: a consideration of the re-emergence and re-positioning of faith and spirituality as spiritual capital in the workplace”, available at: http:/www.chester.ac.uk/sites/ files/chester/Values, $\%$ 20Beliefs $\% 20$ and $\% 20$ Attitudes $\% 20$ in $\% 20$ the $\% 20$ Era $\% 20$ of $\% 20$ Late $\%$ 20Capitalism.pdf (accessed 25 May 2016).

Baptiste, N.R. (2009), "Fun and well-being: insights from senior managers in a local authority", Employee Relations, Vol. 31 No. 6, pp. 600-612.

Barclay, L.J. and Saldanha, M.F. (2016), "Facilitating forgiveness in organizational contexts: exploring the injustice gap, emotions, and expressive writing interventions", Journal of Business Ethics, Vol. 137 No. 4, pp. 699-720.

Beard, S. (2012), "Examining, evaluating, and exploring spiritual capital", available at: http://www. ekklesia.co.uk/research/spiritual_capital (accessed 19 June 2014).

Blanton, J. (2007), Exploring Spirituality in Educational Leadership: Toward a Leadership Framework of Critical Spirituality, unpublished doctoral dissertation, University of North Florida, Jacksonville.

Bouckaert, L. (2011), "The search for a 'profane spirituality", Spiritus: A Journal of Christian Spirituality, Vol. 11 No. 1, pp. 24-37.

Bright, D.S., Winn, B.A. and Kanov, J. (2014), "Reconsidering virtue: differences of perspective in virtue ethics and the positive social sciences", Journal of Business Ethics, Vol. 119 No. 4, pp. 445-460.

Brueller, D. and Carmeli, A. (2011), "Linking capacities of high-quality relationships to team learning and performance in service organizations", Human Resource Management, Vol. 50 No. 4, pp. 455-477.

Brătianu, C. and Bălănescu, G.V. (2008), "Vision, mission and corporate values. A comparative analysis of the top 50 U.S. companies", Management and Marketing, Vol. 3 No. 3, pp. 19-38.

Byrne, C.J., Morton, D.M. and Dahling, J.J. (2011), "Spirituality, religion, and emotional labor in the workplace", Journal of Management, Spirituality and Religion, Vol. 8 No. 4, pp. 299-315.

Caillier, J.G. (2017), "The impact of high-quality workplace relationships in public organizations", Public Administration, Vol. 95 No. 3, pp. 638-653.

Individual spiritual capital

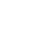


JWAM

13,1

Caldwell, C. and Dixon, R.D. (2010), "Love, forgiveness, and trust: critical values of the modern leader", Journal of Business Ethics, Vol. 93 No. 1, pp. 91-101.

Caldwell, C., Davis, B. and Devine, J.A. (2009), "Trust, faith, and betrayal: insights from management for the wise believer", Journal of Business Ethics, Vol. 84 No. 1, pp. 103-114.

Caldwell, C., Ichiho, R. and Anderson, V. (2017), "Understanding level 5 leaders: the ethical perspectives of leadership humility", Journal of Management Development, Vol. 36 No. 5, pp. 724-732.

Cameron, K. and Caza, A. (2002), "Organizational and leadership virtues and the role of forgiveness", Journal of Leadership and Organizational Studies, Vol. 9 No. 1, pp. 33-48.

Carmeli, A. and Gittell, J.H. (2009), "High quality relationships, psychological safety and learning from failures in work organizations", Journal of Organizational Behavior, Vol. 30 No. 6, pp. 709-729.

Carmeli, A., Friedman, Y. and Tishler, A. (2013), "Cultivating a resilient top management team: the importance of relational connections and strategic decision comprehensiveness", Safety Science, Vol. 51 No. 1, pp. 148-159.

Caza, B.B. and Milton, L.P. (2012), "Resilience at work: building capability in the face of adversity", in Cameron, K.S. and Spreitzer, G.M. (Eds), The Oxford Handbook of Positive Organizational Scholarship, Oxford University Press, New York, NY, pp. 895-908.

Chawla, V. and Guda, S. (2010), "Individual spirituality at work and its relationship with job satisfaction, propensity to leave and job commitment: an exploratory study among sales professionals", Journal of Human Values, Vol. 16 No. 2, pp. 157-167.

Clayton, P. (1997), Implementation of Organizational Innovation, Academic Press, San Diego, CA.

Cooperrider, D.L., Fry, R.E. and Piderit, S.K. (2007), "New designs in transformative cooperation: the growing call and converging conversation", in Piderit, S.K., Fry, R.E. and Cooperrider, D.L. (Eds), Handbook of Transformative Cooperation, Stanford University Press, Stanford, CA, pp. 418-430.

Crabtree (2013), "Worldwide, 13\% of employees are engaged at work", Gallup, available at: https:// news.gallup.com/poll/165269/worldwide-employees-engaged-work.aspx (accessed 21 October 2019).

Crossman, J. (2015), "Eclecticism and commonality in employee constructions of spirituality", Journal of Management, Spirituality and Religion, Vol. 12 No. 1, pp. 59-77.

Crossman, M., Mazutis, D. and Seijts, G. (2013), "In search of virtue: the role of virtues, values and character strengths in ethical decision making", Journal of Business Ethics, Vol. 113 No. 4, pp. 567-581.

Culliford, L. (2014), "The meaning of life diagram: a framework for a developmental path from birth to spiritual maturity", Journal for the Study of Spirituality, Vol. 4 No. 1, pp. 31-44.

Dagenais-Desmarais, V. and Savoie, A. (2012), "What is psychological well-being, really? A grassroots approach from the organizational sciences", Journal of Happiness Studies, Vol. 13 No. 4, pp. 659-684.

De Bruin, B. (2013), "Epistemic virtues in business", Journal of Business Ethics, Vol. 113 No. 4, pp. 583-595.

Decety, J. and Lamm, C. (2006), "Human empathy through the lens of social neuroscience", The Scientific World Journal, Vol. 6, pp. 1146-1163.

Demmrich, S. and Huber, S. (2019), "Multidimensionality of spirituality: a qualitative study among secular individuals", Religions, Vol. 10 No. 613, doi: 10.3390/rel10110613.

Dietz, J. and Kleinlogel, E.P. (2014), "Wage cuts and managers' empathy: how a positive emotion can contribute to positive organizational ethics in difficult times", Journal of Business Ethics, Vol. 119 No. 4, pp. 461-472.

Dutton, J.E. (2003), Energize Your Workplace: How to Create and Sustain High-Quality Connections at Work, Jossey-Bass, San Francisco, CA. 
Dutton, J.E., Lilius, J. and Kanov, J. (2007), “The transformative potential of compassion at work”, in Piderit, S.K., Fry, R.E. and Cooperrider, D.L. (Eds), Handbook of Transformative Cooperation, Stanford University Press, Stanford, CA, pp. 107-126.

Dyck, B. and Schroeder, D. (2005), "Management, theology and moral point of view: towards an alternative to the conventional materialist-individuals ideal-type of management", Journal of Management Studies, Vol. 42 No. 4, pp. 705-735.

Emmons, R.A. (1999), The Psychology of Ultimate Concerns, The Guilford Press, New York, NY.

Exline, J.J. and Bright, D.S. (2011), "Spiritual and religious struggles in the workplace", Journal of Management, Spirituality and Religion, Vol. 8 No. 2, pp. 123-142.

Fotaki, M., Altman, Y. and Koning, J. (2020), "Spirituality, symbolism and storytelling in twenty firstcentury organizations: understanding and addressing the crisis of imagination", Organization Studies, Vol. 41 No. 1, pp. 7-30.

Fredrickson, B.L. (2005), "Positive emotions", in Snyder, C.R. and Lopez, S.J. (Eds), Handbook of Positive Psychology, Oxford University Press, New York, NY, pp. 120-134.

Frostenson, M. (2016), "Humility in business: a contextual approach", Journal of Business Ethics, Vol. 138 No. 1, pp. 91-102.

Fry, L.W. (2003), “Toward a theory of spiritual leadership”, The Leadership Quarterly, Vol. 14 No. 6, pp. 693-727.

Fry, L.W. (2005), "Toward a theory of ethical and spiritual well-being, and corporate social responsibility through spiritual leadership", in Giacalone, R.A. and Jurkiewicz, C.L. (Eds), Handbook of Workplace Spirituality and Organizational Performance, M. E. Sharpe, Armonk, NY, pp. 47-83.

Fry, L.W., Hannah, S.T., Noel, M. and Walumbwa, F.O. (2011), "Impact of spiritual leadership on unit performance", The Leadership Quarterly, Vol. 22 No. 2, pp. 259-270.

George, J.M. (2014), “Compassion and capitalism: implications for organizational studies”, Journal of Management, Vol. 40 No. 1, pp. 5-15.

Giacalone, R.A. and Promislo, M.D. (2010), "Unethical and unwell: decrements in well-being and unethical activity at work", Journal of Business Ethics, Vol. 91 No. 2, pp. 275-297.

Grant, A.M., Christianson, M.K. and Price, R.H. (2007), "Happiness, health, or relationships? Managerial practices and employee well-being tradeoffs", Academy of Management Perspectives, Vol. 21 No. 3, pp. 51-63.

Groen, J.E. (2018), "Inner and outer congruence: an academic's quest to find spiritual wellness and health", Journal for the Study of Spirituality, Vol. 8 No. 2, pp. 120-129.

Hartman, E.M. (2011), "Virtue, profit, and the separation thesis: an Aristotelian view", Journal of Business Ethics, Vol. 99 No. 1, pp. 5-17.

Hoffman, W.M. and McNulty, R.E. (2012), "Transforming faith in corporate capitalism through business ethics", Journal of Management, Spirituality and Religion, Vol. 9 No. 3, pp. 217-236.

Holt, S. and Marques, J. (2012), "Empathy in leadership: appropriate or misplaced? An empirical study on a topic that is asking for attention”, Journal of Business Ethics, Vol. 105 No. 1, pp. 95-105.

Howard, S. and Welbourn, D. (2004), The Spirit at Work Phenomenon, Azure, London.

Humphries, M., Jamil, N. and Jordan, L.-A. (2016), "Invigorating spiritual engagement: reflections for organisational leaders, managers, and 'people-of-faith", Journal of Management, Spirituality and Religion, Vol. 13 No. 2, pp. 143-166.

Ismail, B.M. (2005), The Influence of Intellectual Capital on the Performance of Telekom Malaysia, $\mathrm{PhD}$ Thesis, University Technology Malaysia.

Javaheri, H., Safarnia, H. and Mollahosseini, A. (2013), "Survey relationship between spiritual intelligence and service quality", Interdisciplinary Journal of Contemporary Research in Business, Vol. 4 No. 9, pp. 547-554. 
JWAM

13,1

Johnson, C.E. (2009), "Spirituality and ethical leadership: moral persons and moral managers", in Marques, J., Dhiman, S. and King, R. (Eds), The Workplace and Spirituality: New Perspectives on Research and Practice, Skylight Paths Publishing, Woodstock, VT, pp. 75-86.

Kardec, A. (1868), “O Espiritismo é uma religião?”, Revista Espírita - Jornal de Estudos Psicológicos, Vol. 12 dezembro, pp. 483-495.

Kardec, A. (2003a), The Spirits' Book, Translated from the Le Livre des Esprits, 1857, Allan Kardec Educational Society, Philadelphia, PA.

Kardec, A. (2003b), The Gospel Explained by the Spiritist Doctrine, 2nd ed., (Translated from Le Evangile Selon Le Espiritisme, 1866, 3rd ed.), Allan Kardec Educational Society, Philadelphia, PA.

Kardec, A. (2003c), Genesis - the Miracles and Predictions According to Spiritism, Translated from La Genèse - Les Miracles et les Prédictions Selon le Spiritisme, 1868, Spiritist Alliance for Books, New York, NY.

Kardec, A. (2004), Introduction to the Spiritist Philosophy, Translated from Qu'Est-Ce Que Le Spiritism? [first published 1865], Allan Kardec Educational Society, Philadelphia, PA.

Kardec, A. (2005), Heaven and Hell or the Divine Justice Vindicated in the Plurality of Existences, Translated from the Sixtieth Thousand by Anna Blackwell, 1878, Lake, São Paulo, SP.

Ketola, T. (2006), "From CR-psychopaths to responsible corporations: waking up the inner sleeping beauty of companies", Corporate Social Responsibility and Environmental Management, Vol. 13 No. 2, pp. 98-107.

King, U. (2008), The Search for Spirituality: Our Global Quest for a Spiritual Life, BlueBridge, New York, NY.

Kinjerski, V.M. and Skrypnek, B.J. (2004), "Defining spirit at work: finding common ground", Journal of Organizational Change Management, Vol. 17 No. 1, pp. 26-42.

Kolade, O. and Egbetokun, A. (2018), "Spiritual capital, entrepreneurial resilience and firm-level performance in turbulent environments", available at: https://www.google.com/ur 1 ?sa $=t \& r c t=j \& q=\& e s r c=s \&$ source $=$ web\&cd $=1 \& c a d=$ rja\&uact $=8 \& v e d=2 a h U K E w j L 9 q e t g 8$ DeAhVBCpAKHfsVBPQQFjAAegQIBxAC\&url=http \%3A \%2F \%2Fmecon.nomadit.co.uk\% 2Fpub $\%$ 2Fconference_epaper_download.php5\%3FPaperID \%3D42889\%26MIMEType $\%$ 3Dapplication \%2Fpdf\&usg=AOvVaw2nn-GyfOQdlyNxpmOZJnYI (accessed 7 July 2018).

Kossek, E.E. and Perrigino, M.B. (2016), "Resilience: a review using a grounded integrated occupational approach", The Academy of Management Annals, Vol. 10 No. 1, pp. 729-797.

Kouzes, J.M. and Posner, B.Z. (2009), "The leader's mandate: create a shared sense of destiny", in Hesselbein, F. and Goldsmith, M. (Eds), The Organization of the Future 2: Visions, Strategies, and Insights on Managing in a New Era, Jossey-Bass, San Francisco, CA, pp. 27-36.

Krahnke, K. and Cooperrider, D. (2008), "Appreciative inquiry: inquiring new questions and dreaming new dreams", in Biberman, J. and Tischler, L. (Eds), Spirituality in Business: Theory, Practice, and Future Directions, Palgrave Macmillan, New York, NY, pp. 17-34.

Kruse, E., Chancellor, J. and Lyubomirsky, S. (2017), "State humility: measurement, conceptual validation, and intrapersonal processes", Self and Identity, Vol. 16 No. 4, pp. 399-438.

Lanctot, J.D. and Irving, J.A. (2010), "Character and leadership: situating servant leadership in a proposed virtues framework", International Journal of Leadership Studies, Vol. 6 No. 1, pp. $28-50$.

Lennick, D. and Kiel, F. (2005), Moral Intelligence: Enhancing Business Performance and Leadership Success, Wharton School Publishing, Upper Saddle River, NJ.

Lillard, D.R. and Ogaki, M. (2005), "The effects of spiritual capital on altruistic economic behavior", Unpublished Research Proposal, Cornell University and Ohio State University.

Linnenluecke, M.K. (2017), "Resilience in business and management research: a review of influential publications and a research agenda”, International Journal of Management Reviews, Vol. 19 No. 1, pp. 4-30. 
Lips-Wiersma, M. and Nilakant, V. (2008), "Practical compassion: toward a critical spiritual foundation for corporate responsibility", in Biberman, J. and Tischler, L. (Eds), Spirituality in Business: Theory, Practice, and Future Directions, Palgrave Macmillan, New York, NY, pp. 51-72.

Liu, C.H. and Robertson, P.J. (2011), "Spirituality in the workplace: theory and measurement", Journal of Management Inquiry, Vol. 20 No. 1, pp. 35-50.

Liu, A. (2007), "Measuring spiritual capital as a latent variable", available at: http://www. researchmethods.org/be4capital11 (accessed 22 April 2019).

Lozano, J.M. and Ribera, R. (2004), "A new chance for management - a new challenge for spirituality”, in Zsolnai, L. (Ed.), Spirituality and Ethics in Management, Kluwer Academic Publishers, Dordrecht, pp. 175-185.

Luthans, F., Youssef, C.M. and Avolio, B.J. (2007), Psychological Capital: Developing the Human Competitive Hedge, Oxford University Press, New York, NY.

Malloch, T.R. (2010), "Spiritual capital and practical wisdom", Journal of Management Development, Vol. 29 Nos 7/8, pp. 755-759.

Marschke, E., Preziosi, R. and Harrington, W.J. (2011), "How sales personnel view the relationship between job satisfaction and spirituality in the workplace", Journal of Organizational Culture, Communications and Conflict, Vol. 15 No. 2, pp. 71-110.

Marques, J.F. (2006), "Removing the blinders: a phenomenological study of U.S. based MBA Students' perception of spirituality in the workplace", Journal of American Academy of Business, Vol. 8 No. 1, pp. 55-61.

Marques, J., Dhiman, S. and King, R. (2007), Spirituality in the Workplace: What it is Why it Matters How to Make it Works for You, Personhood Press, Fawnskin, CA.

Mas-Machuca, M. and Marimon, F. (2019), "Holistic spiritual capital: definition and its measurement", International Journal of Organization Theory and Behavior, Vol. 22 No. 1, pp. 96-110.

McGee, J.J. and Delbecq, A.L. (2003), "Vocation as a critical factor in a spirituality for executive leadership in business", in Williams, O.F. (Ed.), Business, Religion, and Spirituality: A New Synthesis, University of Notre Dame Press, Notre Dame, IN, pp. 94-110.

Middlebrooks, A. and Noghiu, A. (2010), "Leadership and spiritual capital: exploring the link between individual service disposition and organizational value", International Journal of Leadership Studies, Vol. 6 No. 1, pp. 67-85.

Mohtar, S., Rahman, I.S.A. and Abbas, M. (2015), "Intellectual capital and its major components", Journal of Technology and Operations Management, Vol. 10 No. 1, pp. 15-21.

Natale, S.M. and Sora, S.A. (2010), "Ethics in strategic thinking: business processes and the global market collapse", Journal of Business Ethics, Vol. 94 No. 3, pp. 309-316.

Owens, B.P., Rowatt, W.C. and Wilkins, A.L. (2012), "Exploring the relevance and implication of humility in organizations", in Cameron, K.S. and Spreitzer, G.M. (Eds), The Oxford Handbook of Positive Organizational Scholarship, Oxford University Press, New York, NY, pp. 260-272.

Palmer, D.A. and Wong, M. (2013), "Clarifying the concept of spiritual capital", Paper Presented at Conference on the Social Scientific Study of Religion the Chinese University of Hong Kong.

Pargament, K.I. and Mahoney, A. (2005), "Spirituality: discovering and conserving the sacred", in Snyder, C.R. and Lopez, S.J. (Eds), Handbook of Positive Psychology, Oxford University Press, New York, NY, pp. 646-659.

Pennings, J.M., Lee, K. and van Witteloostuijn, A. (1998), "Human capital, social capital and firm dissolution", Academy of Management Journal, Vol. 41 No. 4, pp. 425-440.

Robertson, I. and Tinline, G. (2008), "Understanding and improving psychological well-being for individuals and organisational effectiveness", in Kinder, A., Hughes, R. and Cooper, C.L. (Eds), Employee Well-Being Support: A Workplace Resource, John Wiley \& Sons, West Sussex, pp. 39-49.

Rozuel, C. and Kakabadse, N. (2010), "Ethics, spirituality and self: managerial perspective and leadership implications", Business Ethics: A European Review, Vol. 19 No. 4, pp. 423-436. 
JWAM

13,1

140

Schulman, M. (2005), "How to become moral: the sources of moral motivation", in Snyder, C.R. and Lopez, S.J. (Eds), Handbook of Positive Psychology, Oxford University Press, New York, NY, pp. 499-512.

Scott, B.A., Colquitt, J.A., Paddock, E.L. and Judge, T.A. (2010), "A daily investigation of the role of manager empathy on employee well-being", Organizational Behavior and Human Decision Processes, Vol. 113, pp. 127-140.

Sekerka, L.E. and Fredrickson, B.L. (2008), "Establishing positive emotional climates to advance organizational transformation", in Ashkanasy, N.A. and Cooper, C.L. (Eds), Research Companion to Emotion in Organizations, Edward Elgar Publishing, Northampton, MA, pp. 531-545.

Sekerka, L.E., Vacharkulksemsuk, T. and Fredrickson, B.L. (2012), "Positive emotions: broadening and building upward spirals of sustainable enterprise", in Cameron, K.S. and Spreitzer, G.M. (Eds), The Oxford Handbook of Positive Organizational Scholarship, Oxford University Press, New York, NY, pp. 168-177.

Sharonova, S. and Ildarhanova, C. (2015), "Spiritual capital as a fundamental element of cultural capital”, Sociology Study, Vol. 5 No. 10, pp. 785-793.

Simmons, B.L. and Nelson, D.L. (2007), "Eustress at work: extending the holistic stress model", in Nelson, D.L. and Cooper, C.L. (Eds), Positive Organizational Behavior, Sage, London, pp. 40-53.

Srirangarajan, G.S. and Bhaskar, R.K. (2011), "Key dimensions of spirit at work-an Indian perspective”, Journal of Human Values, Vol. 17 No. 2, pp. 93-120.

Stead, J.G. and Stead, W.E. (2014), "Building spiritual capabilities to sustain sustainability-based competitive advantages", Journal of Management, Spirituality and Religion, Vol. 11 No. 2, pp. 143-158.

Steffler, D.J. and Murdoch, K.C. (2017), "Meaning and spirituality: a thematic analysis", International Journal of Existential Psychology and Psychotherapy, Vol. 7 No. 1, pp. 1-22.

Su, H.Y. (2014), "Business ethics and the development of intellectual capital", Journal of Business Ethics, Vol. 119 No. 1, pp. 87-98.

Tacey, D. (2004), The Spirituality Revolution: The Emergence of Contemporary Spirituality, BrunnerRoutledge, New York, NY.

Tangney, J.P. (2005), "Humility", in Snyder, C.R. and Lopez, S.J. (Eds), Handbook of Positive Psychology, Oxford University Press, New York, NY, pp. 411-419.

Thaker, K.B. (2009), "Approaches to implement spirituality in business”, Journal of Human Values, Vol. 15 No. 2, pp. 185-198.

Tran, K.T., Nguyen, P.V., Dang, T.T.U. and Ton, T.N.B. (2018), "The impacts of the high-quality workplace relationships on job performance: a perspective on staff nurses in Vietnam", Behavioral Sciences, Vol. 8 No. 109, doi: 10.3390/bs8120109.

Vasconcelos, A.F. (2010), "Spiritual development in organizations: a religious-based approach", Journal of Business Ethics, Vol. 93 No. 4, pp. 607-622.

Vasconcelos, A.F. (2013), "Examining workers' perception of spirituality in the workplace: an exploratory study", Management and Marketing, Vol. 8 No. 2, pp. 231-260.

Vasconcelos, A.F. (2015), "The spiritually-based organization: a theoretical review and its potential role in the third millennium", Cadernos EBAPE.BR, Vol. 13 No. 1, pp. 183-205.

Vasconcelos, A.F. (2017a), "The scope and implications of spirituality: a dual approach", Organizações \& Sociedade, Vol. 24 No. 83, pp. 600-617.

Vasconcelos, A.F. (2017b), "High intergenerational connections: a film-based inquiry", Management Research Review, Vol. 40 No. 12, pp. 1298-1315.

Vasconcelos, A.F. (2018), "Older workers as a source of wisdom capital: broadening perspectives", Revista de Gestão, Vol. 25 No. 1, pp. 102-118. 
Vazin, D. (2013), Spirituality and Health: Implications for Policy and Practice, doctoral dissertation, University of La Verne.

Verter, B. (2003), "Spiritual capital: theorizing religion with Bourdieu against Bordieu", Sociologial Theory, Vol. 21 No. 2, pp. 150-174.

Individual spiritual capital

Vitell, S.J., King, R.A., Howie, K., Toti, J.F., Albert, L., Hidalgo, E.R. and Yacout, O. (2016), "Spirituality, moral identity, and consumer ethics: a multi-cultural study", Journal of Business Ethics, Vol. 139 No. 1, pp. 147-160.

Weiss, H.M. (2002), "Conceptual and empirical foundations for the study of affect at work", in Lord, R.G., Klimoski, J. and Kanfer, R. (Eds), Emotions in the Workplace: Understanding the Structure and Role of Emotions in Organizational Behavior, Jossey-Bass, San Francisco, CA, pp. 20-63.

Williams, O.F. (Ed.) (2003), Business, Religion, and Spirituality: A New Synthesis, University of Notre Dame Press, Notre Dame, IN.

Wolman, R.N. (2001), Thinking with Your Soul: Spiritual Intelligence and Why it Matters, Harmony Books, New York, NY.

Worthington, E.L. Jr, Berry, J.W., Shivy, V.A. and Browstein, E. (2005), "Forgiveness and positive psychology in business ethics and corporate social responsibility", in Giacalone, R.A., Jurkiewicz, C.L. and Dunn, C. (Eds), Positive Psychology in Business Ethics and Corporate Responsibility, Information Age Publishing, Greenwich, CT, pp. 265-284.

Xavier, F.C. (By the Spirit Emmanuel) (2006), The Pathway, the Truth and Life, Translated from Caminho, Verdade e Vida [first edition 1949], International Spiritist Council, Brasília, DF.

Xavier, F.C. (By the Spirit Emmanuel) (2013), Living Spring, Translated from Fonte Viva [first edition 1956], Edicei of America, Miami, FL.

Youndt, M.A. and Snell, S.A. (2004), "Human resource configurations, intellectual capital, and organizational performance", Journal of Managerial Issues, Vol. 16 No. 3, pp. 337-360.

Zinnbauer, B.J. and Pargament, K.I. (2005), "Religiousness and spirituality", in Paloutzian, R.F. and Park, C.L. (Eds), Handbook of the Psychology of Religion and Spirituality, The Guilford Press, New York, NY, pp. 21-42.

Zohar, D. (2010), "Exploring spiritual capital: an interview with Danah Zohar", Spirituality in Higher Education Newsletter, Vol. 5 No. 5, pp. 1-8.

Zohar, D. and Marshall, I. (2004), Spiritual Capital: Wealth We Can Live by, Berret-Koehler Publishers, San Francisco, CA.

\begin{abstract}
About the author
Anselmo Ferreira Vasconcelos got a BS in Social Communication from Escola Superior de Propaganda e Marketing (ESPM) and MS in Management from Pontifical Catholic University both in São Paulo. As an independent researcher, he has published his work at European Journal of Marketing, International Journal of Organizational Analysis, International Journal of Workplace Health Management, Journal of Business Ethics, Journal of Management and Organization, Journal of Management Development, Management Decision, Management and Marketing, Management Research, Management Research Review, The Qualitative Report and several Brazilian academic journals about prayer effects on organizational life, internal (de)marketing, spirituality in the workplaces, societal marketing, among other topics. He regularly writes to Brazilian non-refereed publications about religion and spirituality themes. Finally, he is also the author of two books (in Portuguese) upon spirituality in the workplace, Espiritualidade no Ambiente de Trabalho: Dimensões, Reflexões e Desafios published by Editora Atlas (2008) and, older workers and diversity, Talentos Maduros, Diversidade e Inclusão: Uma Visão Crítica published by Editora da UFRGS (2020). Anselmo Ferreira Vasconcelos can be contacted at: afv@uol. com.br
\end{abstract}

For instructions on how to order reprints of this article, please visit our website:

www.emeraldgrouppublishing.com/licensing/reprints.htm

Or contact us for further details: permissions@emeraldinsight.com 